\title{
Squamous cell carcinoma of the stomach
}

\section{To the Editor:}

I read with interest the recent article by Marubashi et al. [1]. They reported a patient with primary squamous cell carcinoma (SCC) of the stomach which had been effectively managed by chemotherapy and gastrectomy, and reviewed the 32 cases reported in the Japanese literature.

I wonder why the authors omitted any reference to the literature in English reporting cases and discussing the histogenesis of pure SCC of the stomach [2-7]. Because Gastric Cancer is a new international journal for clinicians and researchers all over the world, authors should be thorough in consulting the literature in English.

In 1986, Mori et al. [2] reported three cases of SCC of the stomach and discussed the pathogenesis of gastric SCC with respect to their detailed and extensive observations and literature review [8,9]. They proposed two possible mechanisms for the development of primary SCC of the stomach: (1) overgrowth of the squamous component in a primary adenocarcinoma, and (2) malignant transformation of squamous metaplasia of the stomach $[2,8,9]$. In the case of Marubashi et al., anticancer drugs, including 5-fluorouracil and cisplatin, were given preoperatively, and histologically most of the tumor showed necrotic change on the resected stomach. The pathogenesis of their tumor is unknown, and no conclusive statement about the pathogenesis of gastric SCC can be made on the basis of their findings.

Although the authors believe their patient to be the 32nd case of gastric SCC in Japan, a search of the Japanese-language literature revealed additionally more than ten well-documented cases of primary SCC of the stomach [10-13]. Furthermore, three cases reported by Mori et al. [2] must be included in the table of the Japanese cases. In the era of instant electronic access to stored medical bibliography, authors should be cautious before declaring their case "the 32nd case of SCC of the stomach (in Japan)".
I hope this letter will contribute to the further understanding of gastric cancer and to the fruitful growth of Gastric Cancer.

Yosuke Adachi

First Department of Surgery, Oita Medical University, 1-1 Idaigaoka, Hasama-machi, Oita 879-5593, Japan

\section{References}

1. Marubashi S, Yano $\mathrm{H}$, Monden $\mathrm{T}$, Tateishi $\mathrm{H}$, Kanoh $\mathrm{T}$, Iwazawa $\mathrm{T}$, et al. Primary squamous cell carcinoma of the stomach. Gastric Cancer 1999;2:136-41.

2. Mori M, Iwashita A, Enjoji M. Squamous cell carcinoma of the stomach: report of three cases. Am J Gastroenterol 1986;81:33942.

3. Weisbrot IM. Squamous carcinoma of the stomach: a rarity or an evolving problem? (Editorial) Am J Gastroenterol 1986;81: 398.

4. Bonnheim DC, Sarac OK, Fett W. Primary squamous cell carcinoma of the stomach. Am J Gastroenterol 1985;80:91-4.

5. Callery CD, Sanders MM, Pratt S, Turnbull AD. Squamous cell carcinoma of the stomach: a study of four patients with comments on histogenesis. J Surg Oncol 1985;29:166-72.

6. Ruck P, Wehrmann M, Campbell M, Horny HP, Breucha G, Kaiserling E. Squamous cell carcinoma of the gastric stump: a case report and review of the literature. Am J Surg Pathol 1989; 13:317-24.

7. Volpe CM, Hameer HR, Masetti P, Pell M, Shaposhnikov YD, Doerr RJ. Squamous cell carcinoma of the stomach. Am Surg 1995;61:1076-8.

8. Mori M, Iwashita A, Enjoji M. Adenosquamous carcinoma of the stomach: a clinicopathologic analysis of 28 cases. Cancer 1986;57: 333-9.

9. Mori M, Fukuda T, Enjoji M. Adenosquamous carcinoma of the stomach: histogenetic and ultrastructural studies. Gastroenterology 1987;92:1078-82.

10. Fujikawa M, Yoshikawa K, Nishimura M, Yamanishi H, Baba Y, Okamura H, Han N, Ito A. Squamous cell carcinoma and adenosquamous cell carcinoma of the stomach: report of two cases (in Japanese). Jpn J Gastroenterol Surg 1987;20:800-3.

11. Kurebayashi J, Shiozaki H, Uchida K, Matsumoto H. A case of squamous cell carcinoma of the body of the stomach (in Japanese). J Jpn Surg Assoc 1987;48:63-7.

12. Jozaki H, Murayama H, Maekawa T, Kikuchi M, Sato M. A case of early-stage squamous cell carcinoma of the stomach 
(in Japanese). Gan no Rinsho (Jpn J Cancer Clin) 1988;34:102530 .

13. Sugiyama T, Ono A, Sato Y, Yoshida H, Endo K, Imai K, Yabana T, Yauchi A. A case of squamous cell carcinoma of the stomach: immunohistochemical analysis (in Japanese). Jpn J Gastroenterol $1989 ; 86: 1525-8$.

\section{Authors' Reply}

\section{To the Editor:}

The authors have read with interest the Letter to the Editor by Dr. Yosuke Adachi. In this letter, he hypothesizes about the lack of literature in English and the more than ten well-documented cases of squamous cell carcinoma (SCC) of the stomach in the Japanese literature. We also reviewed approximately 80 cases of SCC of the stomach reported in English. Such tumors have been variously termed adenoacanthoma, adenosquamous carcinoma, pure squamous cell carcinoma, adenocancroid, and muco-epidermoid carcinoma [1]. The term "SCC of the stomach" is imprecisely used to include all those conditions. In the Japanese Classification of Gastric Carcinoma [2], SCC of the stomach is strictly defined as a tumor that consists entirely of SCC. If the components of adenocarcinoma exist in the tumor of SCC, it is diagnosed as adenosquamous carcinoma. On histopathological examination, there were no lesions of adenocarcinoma in our case because the sections stained with CEA, CA19-9, PAS, alcian blue, and mucicarmine showed no evidence of an adenocarcinoma component although the origin of necrotic granulation was unclear. The sections stained with cytokeratine $5,6,8,17$, and 19 were positive, strongly indicating that the cancer cells were derived from epithelial cells. These findings confirmed that our case was pure SCC of the stomach. As we reviewed only the literature on pure SCC of the stomach, the references [3-9] that Dr. Adachi quoted were omitted. They included cases of adenosquamous carcinoma and diagnosis from a biopsy specimen only. Pure SCC of the stomach is a rare tumor, described in only 22 patients since 1905 in the English literature from all over the world [10-11], and in 31 cases in the Japanese literature [12].

The authors accept Dr. Adachi's comment that the pathogenesis of gastric SCC should be discussed thoroughly. The pathogenesis of pure gastric SCC remains unclear even now. There are several theories about the mechanism of its development: (1) the foci of heterotopic squamous epithelium, (2) squamous metaplasia, (3) totipotential stem cells, and (4) overgrowth of the squamous element in a primary adenocarcinoma $[13,14]$. In recent reports $[15,16]$, adenocarcinomarelated antigens such as CA19-9 were found in SCC of the stomach and the reports' authors subscribed to the fourth theory, that the tumor originates from adenocarcinoma and changes to SCC. In our case, no histological sign of adenocarcinoma in the tumor or squamous metaplasia in the gastric mucosa around the SCC could be identified. Therefore, we can speculate that the pathogenesis of this case might be (1) the foci of heterotopic squamous epithelium or (2) totipotential stem cells.

Hiroshi Yano

Department of Surgery, Osaka Teishin Hospital, 2-6-40 Karasugatsuji, Tennoji-ku, Osaka 543-0042, Japan

\section{References}

1. Volpe CM, Hameer HR, Masetti P, Pell M, Shaposhnikov YD, Doerr RJ. Squamous cell carcinoma of the stomach. Am Surg 1995;61:1076-8.

2. Japanese Research Society for Gastric Cancer. Japanese classification of gastric carcinoma. 1st English ed. Tokyo: Kanehara, 1995.

3. Mori M, Iwashita A, Enjoji M. Squamous cell carcinoma of the stomach: report of three cases. Am J Gastroenterol 1986;81:33942.

4. Mori M, Iwashita A, Enjoji M. Adenosquamous carcinoma of the stomach: a clinicopathologic analysis of 28 cases. Cancer 1986;57: 333-9.

5. Mori M, Fukuda T, Enjoji M. Adenosquamous carcinoma of the stomach: histogenetic and ultrastructural studies. Gastroenterology 1987;92:1078-82.

6. Fujikawa M, Yoshikawa K, Nishimura M, Yamanishi H, Baba Y, Okamura $\mathrm{H}$, et al. Squamous cell carcinoma and adenosquamous cell carcinoma of the stomach: report of two cases (in Japanese). Jpn J Gastroenterol Surg 1987;20:800-3.

7. Kurebayashi J, Shiozaki H, Uchida K, Matsumoto H. A case of squamous cell carcinoma of the body of the stomach (in Japanese). J Jpn Surg Assoc 1987;48:63-7.

8. Jozaki H, Murayama H, Maekawa T, Kikuchi M, Sato M. A case of early-stage squamous cell carcinoma of the stomach (in Japanese). Jpn J Cancer Clin 1988;34:1025-30.

9. Sugiyama T, Ono A, Sato Y, Yoshida H, Endo K, Imai K, et al. A case of squamous cell carcinoma of the stomach: immunohistochemical analysis (in Japanese). Jpn J Gastroenterol 1989;86: 1525-8.

10. Bowswell JT, Helwig EB. Squamous cell carcinoma and adenoacanthoma of the stomach. Cancer 1965;18:181-92.

11. Altshuler JH, Shaka JA. Squamous cell carcinoma of the stomach. Review of the literature and report of a case. Cancer 1966;19:831-8.

12. Marubashi S, Yano H, Monden T, Tateishi H, Kanoh T, Iwazawa $\mathrm{T}$, et al. Primary squamous cell carcinoma of the stomach. Gastric Cancer 1999:2:136-41.

13. Rioux A, Masse S. Pure squamous cell carcinoma of the stomach. Can J Surg 1979;22:238-9.

14. Callery CD, Sanders MM, Pratt S, Turnbull AD. Squamous cell carcinoma of the stomach: a study of four patients with comments on histogenesis. J Surg Oncol 1985;29:166-72.

15. Shimizu Y, Tanaka T, Nakae A, Matsui S, Shimode Y, Yoshida J, et al. A case of squamous cell carcinoma of the stomach (in Japanese). J Jpn Surg Assoc 1993;54:2597-601.

16. Aoki T, Nakanishi K, Kamiizumi $Y$, Takagi $T$, Miyata M, Yamashiro K. A case of squamous cell carcinoma of the stomach (in Japanese). J Jpn Gastroenterol Surg 1996;29:72731. 